\title{
ЕДУКАЦИЈА КАО ПРЕТПОСТАВКА УСПЕШНОГ РАЗВОЈА СТРАТЕШКИХ СТУДИЈА 1
}

\author{
проф. др Зоран Јефтић²
}

\section{Апстракт}

Као интегрални део политичких наука, међународних односа или још ближе одређено безбедносних студија, стратешке студије се могу поимати као веза између војних средстава и политичких циљева. То у теорији, а и пракси подразумева интердисциплинарни приступ изучавању, почевши од политике, економије социологије, психологије. технологије, геопростора, до структуре снага и тактике. Стратешко промишљање, а и сама стратегија потребна је не само за доносиоце државних одлука, војсковође, носиоце моћи у великим корпорацијама, већ и за свакодневни живот и решавање проблема и достизање одређених циљева које проглашавамо стратешким и који немају рутинских карактер. Позивамо се на стратегију сваки пут када достизање циља није једноставно и када се захтева ефикасан и ефективан приступ и редослед у процедурама и поступцима. Доношење стратегијске одлуке подастре се увек пред људе највеће моћи, оне који су далеко важнији од саветодаваца или задужених за њено спровођење. За све њих, сложеност појаве, велики број фактора које је потребно узети у разматрање како би се повећале шансе за достизање циља, намеће потребу за адекватном едукацијом стратешких студија, од консултовања великог броја публикација до студијских програма на свим нивоима академског школовања. Рад ће се бавити питањем образовања као предусловом за развој стратегијске мисли и способности, као и приказом развоја студијских програма и праксе студијских курикулума Стратешких студија у земљама европског простора високошколског образовања - ЕНЕА. Имајући у виду значај изучавања стратешких студија на свим нивоима академског школовања, у изради рада се полази од основне претпоставке да студијски програми, који се односе на Стратешке студије, нису по садржају и обиму у довољној мери присутни на основним академским студијама. Резултат овога рада требало би да укаже на потребу сагледавања нове агенде безбедности и стратегије, и сходно томе увођење савремених програмских садржаја стратешких студија намењених будућим цивилним и војним експертима, као и доносиоцима стратешких одлука.

Кључне речи: стратешке студије, стратегија образовања, студијски програми

1 Чланак је резултат рада на пројекту Министарства просвете, науке и технолошког развоја Републике Србије, на основу потписаног Уговора о реализацији и финансирању НИО у 2020. години, као и Плана рада НИО Факултета безбедности за 2020. годину.

${ }^{2}$ Ванредни професор, Универзитет у Београду, Факултет безбедности. Е-пошта: zjeftic@ymail.com 


\section{УВОД}

Циклично кретање академске мисли од утопијске идеје колективне безбедности, преко периода блоковског сучељавања, колапса Совјетског Савеза и распада Варшавског пакта, довела су до поновног критичког осврта на реалистичку теорију стратегије и постхладноратовску еуфорију достизања мира кроз развој концепта индивидуалне националне и међународне безбедности. Нова безбедносна парадигма, настала нестанком блоковске поделе света, увела је у академску заједницу тезу да су безбедносне и стратешке студије питања прошлог времена. Деманти су уследили у веома кратком року и савремена безбедносна кретања 21. века показала су потребу озбиљнијег изучавања стратешких студија. Томе су значајно допринели рат у Ираку, сукоби на простору бивше Југославије, појава Ал Каиде и напад на Пентагон и Светски трговински центар, рат у Авганистану, терористички напади у Европи, претње сајбер ратом и хибридни сукоби. ${ }^{3}$

Уједно, као последица нових невојних тема безбедности, подржаних са безбедносним феноменима савременог доба и невојним носиоцима тих појава, природно су наметнула тематску област стратешких студија. Иако се стратегија нуди као начин промишљања за свакодневни живот и све постојеће професије, њу свакако доминантно везујемо за политичке актере, на нивоу безбедности, који је стављају у промет увек када постоји изражена потреба за анализом расположивих ресурса и начина њихове употребе.

Бављење проблематиком стратегије и питањима од интереса за Стратешке студије не треба изједначавати са покушајем успостављањем Стратешких студија као научне дисциплине, покренуте тек након Другог светског рата. Бернард Броди (Bernard Brodie) у свом раду Стратегија као наука (Strategy as a Science), објављеном 1949. године, упућује на могућности научних основа стратегије и један је од првих аутора који заступа наведену тезу. ${ }^{4}$

Радови о стратегији, пре свега ратоводству, потичу од Старих Грка, Римљана, Кинеза и Европљана у новијем добу. Како би се стратешке студије могле поставити на реалне академске основе, нужно их је излучити као посебну област безбедносних наука и следствено томе, у оквирима високошколског образовања развијати наставне програме за њено изучавање. Полазећи од изнетог става, рад тежи томе да понуди основни приказ појма стратегије и стратешких студија. Други део рада биће посвећен студијским програмима и пракси студијских курикулума Стратешких студија у земљама европског простора високошколског образовања - ЕНЕА. Циљ овога рада уоквирен је указивањем на потребу сагледавања нове агенде безбедности и стратегије, и сходно томе, увођењу савремених програмских садржаја Стратешких студија, намењених будућим цивилним и војним експертима, као и доносиоцима стратешких одлука.

\footnotetext{
3 John Baylis, James J. Wirtz, Colin S. Gray, Strategy in the Contemporary Word, Oxford University Press, 2019.

${ }^{4}$ Bernard Brodie, „Strategy as a Science“, World Politics, July 2019, p. 468.
} 


\section{ПОЈАМ СТРАТЕШКИХ СТУДИЈА}

Етимологија стратегије сеже у класичну Грчку, Средњи век, а чак и у модерном добу доминира „уметност рата“. Реч стратегија је почела да се користи у Британији, Француској и Немачкој тек у касном осамнаестом веку, рефлектујући на просветитељски оптимизам да рат - као и све друге сфере људских послова може имати користи од примене разума. Класици као што су Сун Цу (Sun Tzu), Лидл (Liddell Hart), Клаузевиц (Carl von Clausewitz), Жомини (Baron De Jomini) и Бофр (André Beaufre), стратегију поимају у ужем облику, пројектујући је кроз употребу војне силе за достизање циљева рата. Они траже победу по разумном утрошку средстава, пожељно кроз доминантну употребу памети, а не насиља.

Један од присутних проблема јесте и чињеница да не постоји усаглашена дефиниција стратегије којом би се дао оквир и поље деловања. Ловренс Фридман (Lawrence Фreedman) поставља питање, да ли се реч стратегија може применити на борбене планове, политичку кампању, пословне договоре или на начине суочавања са стресом свакодневног живота, а да не постане бесмислено. Он заступа становиште да је стратегија и даље најбоља реч која постоји за изражавање покушаја да се унапред размисли о радњама, расположивим ресурсима потребним за достизање пројектованог циља. Сматра, што је и прихватљиво, да игра око стратешких студија и стратегије није проблематична уколико се ради о неживим предметима. Ако стратегијску игру водимо са присуством других људи, тамо где имамо потенцијални или стварни конфликт, присутно је сукобљавање интереса и потрага за различитим решењима. Инхерентна непредвидивост људске делатности, услед случајних догађаја, као и поступака противника, али и погрешних потеза савезника и пријатеља, пружа шансу за успех, бољу стратешку замисао и успешније стратегијско планирање. Позивајући се на колумнисту Метју Париса (Matthew Parris) и става да је свепрусутност стратегија која се повезује са активностима које су везане за било који пожељан крај, али и чињеницу да уз непримерену употребу није другачије од осталих сродних речи, попут власти и политике. 5

Бејлис и Вирц (John Baylis, James J. Wirtz) дали су свој избор дефиниција стратегија од Клаузевица до Фридмана кроз које се може сагледати развој стратегијске мисли око основног појма стратегије у последња два века. 6

\section{„Стратегија је употреба и ангажовање за потребе циљева рата“, Carl von Clausewitz „Стратегија је практична примена ресурса за постизање циљева рата“, Von Moltke „Стратегија је уметност расподеле и употребе војних ресурса за достизање политичких циљева, Liddell Hart}

„Стратегија је ... уметност дијалектике снаге, или много прецизније, дијлектика двају супростављених жеља, употребе снага усмерених на решавање њихових неспоразума“, Andre Beaufre

\footnotetext{
${ }^{5}$ Lawrence Freedman, Strategy A History, Oxford University Press, Oxford, 2013.

${ }^{6}$ John Baylis, James J. Wirtz, Introduction Strategy in Contemporary World, in John Baylis, James J. Wirtz, Colin S. Gray, Strategy in the Contemporary Word, Oxford University Press, 2019, p 4
} 
„Стратегија је ultimately о ефикасној употреби моћи“, Gregory D. Foster

„Стратегија је план акције усмерен у правцу достизања неког краја, са заједничким циљем развијања система мера за његово достизање“, J. C. Wylie

„Стратегија је процес у сталном прилагођавању условима и окружењу у променљивом свету у коме доминирају неизвесност и двосмисленост ("uncertainty and ambiguity dominate"), W. Murray and M. Grimslay

„Стратегија је ништа мање него свеопшти план за „utilizing capacity for armed coercion“ у вези са економијом, дипломатијом психолошким инструментима моћи као би се подржала већа ефикасност спољне политике са отвореним, прикривеним средствима (overt covert and tacit means)", Robert Osgood

„...зато је стратегија доминантно политички чин. Ради се о појави више ситуације него што би се могло претпоставити у односу на почетни однос снага. Она је уметност креирања моћи“, Lawrence Freedman

Засигурно се савремена стратегијска мисао бави овом облашћу далеко шире од војних операција, улазећи дубоко у интердисциплинарни приступ. Она мора обухватити област војне мисли, технологије, геополитике, социологије, психологије, економије и политике. Стога је нужно присуство истраживача и практичара са различитим академским образованима и експертским знањима и полазном премисом да се стратегија мора поимати као научни инструмент за решавање практичних проблема. ${ }^{7}$ Као што је и Клаузевиц тврдио да је рат озбиљан посао да би био остављен генералима, тако се може рећи и за изучавање стратегије. Она мора бити проматрана од цивилних академаца који имају војна предзнања, али истовремено и од стране политички сензитивних војника. То захтева и постојање адекватних цивилно-војних односа и развијеног демократског надзора над сектором одбране, искрено прихваћеним од стране цивилних, али и војних актера.

Како наводе Бејлис и Вирц, у дефинисању појма стратегије Колин Греј (Colin Gray) је у свом раду „Модерна стратегија“ идентификовао три области које опредељују стратегију: народ и политика; припреме за рат; прави рат. Сваку од наведених области разрадио је кроз одређене димензије. ${ }^{8}$ Развијајући идеју, Колин Греј сматра да Стратешке студије не могу бити комплетне уколико се испусти било која од наведених димензија9. Стога се стратешке студије морају посматрати као посебна област, уже поимана од студија безбедности с обзиром на то да употреба војних ефектива у сфери безбедности захтева посебну пажњу. У дефинисању стратегије Колин Греј је становишта да она представља начин усмеравања и употребе свих расположивих средстава за достизање постављеног циља. ${ }^{10}$

\footnotetext{
7 Исто.

${ }^{8}$ Народ и политика народ, друштво, култура, политика и етика; Припреме за рат; економија и логистика, организација, војна администрација, обавештајна делатност, стратегијске теорије и доктрина, технологија; Прави рат војне операције, командовање, простор, време сукоб (friction) и противник.

9 John Baylis, James J. Wirtz, op. cit. p. 6.

${ }^{10}$ Colin Gray, Strategy and Politics, Routledge, London and New York, 2016, p.15.
} 
Нова безбедносна парадигма и појава великог броја невојних ризика није умањила значај државоцентричниог модела безбедности. Остао је значај војске и војних операција и потреба њеног изучавања у свим аспектима од политике до тактике. Дешавања у последњих тридесет година потврдила су чињеницу да је војна моћ, поред еуфорије настале крајем прошлог века, остала и даље инструмент за достизање политичких циљева, тако да су и стратешке студије актуелне и данас, бар на нивоу прошлих времена. Владимир Ајзенхамер износи тезу да се претње које имају невојни карактер, са становишта стратешких студија, морају узети у обзир и разматрати само уколико су процењене последице државоцентричне и уколико могу нанети штету националној безбедности. 11

Истовремено, постмодерни период развоја војске према Москосу обухвата време после пада Берлинског зида, а своју другу фазу започиње терористичким нападом на САД.12 Основну разлику модерне и постмодерне војске види у различитој перцепцији претње кроз померања, од војних ка бројним невојним аспектима безбедности, како на националном, тако и на међународном плану. Присуство великог броја недржавних актера у спровођењу насиља поима се као „револуција у војним пословима“. То уједно захтева све веће присуство и учешће цивила у војним операцијама, као и стање цивилно-војног парадокса уз све већу повезаност у удаљеност оружаних снага од друштва уз потребу за примереним политичко културним обликом организованог насиља.

Све те промене нису пореметиле Клаузевицеу тезу да је рат продужење политике другим средствима, али свакако са нови средствима, формама и процедурама које су предмет изучавања стратешких студија у савременом свету. Као посебан сегмент стратешких студија издваја се и одбрамбено планирање, којим се прави стратегијски мост ка припреми и ангажовању војних ресурса.

Не улазећи у детаљнију анализу и теоријску расправу предмета истраживања стратешких студија, метода и осавремењивање поља истраживања, које користи, као и сврсисходности њеног издвајања као посебне научне дисциплина, сматрам прихватљивим виђење Бејлиса и Вирца и њихово смештање стратешких студија у односу на политичке науке, међународне односе и безбедносне студије. ${ }^{13}$

\section{Едукација из области стратегије}

Основни недостатак у садашњем тренутку едукације из области стратегије према Греју односи се на недостатак опште теорије о стратегији. ${ }^{14}$ Како би се схватила

11 Владимир Ајзенхамер, „Стратешке студије од војних наука до студија безбедности“, у зборнику: Науке безбедности - врсте и облици, Универзитет у Београду, Факултет безбедности, 2020, стр. 97.

12 Зоран Јефтић, Мирослав Младеновић и Вања Роквић, Основе цивилно-војних односа, Универзитет у Београду Факултет безбедности, 2014, стр 27.

13 John Baylis, James J. Wirtz, op.cit., p. 13.

${ }^{14}$ Colin S. Gray, "The Practice of Strategy", in: John Baylis, James J. Wirtz, Colin S. Gray, "Strategy in the Contemporary Word", Oxford University Press, 2019, p. 391. 
природа и карактер стратегије, потребно је за почетак достићи сагласност око значења термина стратегије, око њеног политичког, социокултуролошког, економског, технолошког, војног, географског и историјског садржаја, као и око извршења саме стратегије кроз промишљање о тешкоћама и слабостима, времену, простору, логистици, обавештајној делатности, војној доктрини и стратегијској вези. Један од разлога за осамостаљење стратешких студија и потреба њиховог академског изучавања, јесте и чињеница да међународни односи као њихов старији брат препознају изучавање рата само пре и после тог догађаја. Стратешке студије имају шири обухват на све три фазе рата, које су међусобно зависне кроз понашање које постаје узрок, механизме насиља који обликују одлуке сходно њиховим политичким апликацијама. 15

Крај Хладног рата вратио је студије безбедности у њихову трећу фазу и поновно отварање питања о узроцима рата и мира, ефектима опште расподеле моћи у међународним односима, економским и идеолошким утицајима на обрасце сукоба и сарадње међу државама. Шездесетих година двадесетог века Бофр (Bofr) констатује да постоји потенцијал у оквиру америчких института за истраживање стратешких студија. Међутим, однос истраживачких института и истраживања и планова и програма није пропорционалан ако се узме у обзир чињеница да постоји већи број института који имају потенцијал за бављење стратешким студијама него што има образовних програма који се баве преношењем знања из ове области. Најлогичнији одговор се може пронаћи у још увек присутној парадигми да се стратешке студије посматрају као област која припада безбедносним студијама, а још шире посматрано - међународним односима и политичким наукама. 16 Таква врста поимања потврдила је и чињеницу да академски замах стратешких студија од краја деведесетих година није праћен адекватним институционалном (универзитетском) подршком. Како наводи Ричард Бетз (Richard K. Betts), на универзитетима у САД не постоје организационе јединице која изучавају стратешке или студије рата, а да је у Великој Британији супротан случај. То нам уједно показује да је постојала и постоји разлика између интелектуалне и институционалне логике.

Суштина стратегије требало би да буде интеграција пре свега две дисциплине политичке науке и војне науке. С обзиром на развијеност политичких наука, интердисциплинарна стратегија пати од недостатка потпуно устројене академске дисциплине војне науке. ${ }^{17}$ Међутим, да би се у потпуности разумеле све три фазе рата, узроци, спровођење и последице потребно је интердисциплинарно знање и о економији, социологији, психологији, географији и технологији.

Нужно је назначити и уже области изучавања које се односе на студије одбране, односно, студије војске као њеног ужег дела. Обе наведе области имају значајно

15 Richard K. Betts, "Should Strategic Studies Survive?", World Politics, Vol. 50, No. 1, Fiftieth Anniversary Special Issue, 1997, p. 10.

16 Андре Бофр, Увод у стратегију. Војноиздавачки завод, Београд, 1968, стр. 19.

17 Richard K. Betts, op. cit. p. 23. 
мањи захват интересовања, фокусирајући се на систем одбране сваке појединачне земље, његову нормативну, организациону и функционалну устројеност и војску као њен носећи део. Сходно наведеном, стратешке студије обухватају разматрања студија одбране и студија војске, стављајући их у контекст међудржавних односа са фокусом на употребу силе и претњу употребом силе.

Упркос проблемима око остваривања аутономије стратешких студија и њеног издвајања из окриља наука безбедности, један број истраживачких института, као и универзитета, уочио је значај наведене области у оквиру својих студијских програма и препознао потребу и интерес да уведе и програмске садржаје који се односе на стратегију и стратешке студије. За потребе Факултета безбедности Универзитета у Београду и увођења у наставне програме, садржаја који дотичу области међународних и стратешких студија извршена је анализа једног броја значајнијих истраживачких института и универзитета у свету. ${ }^{18}$

Најоптималнија анализа наставних програма омогућила је претрагу студијских програма у Немачкој преко Немачке службе за академску размену (DAAD) кроз филтер студија мира и безбедности (Peace and Security).19 Добијено је 37 резултата за основне студије и 185 резултата за мастер студије. Прегледом 37 програма основних студија уочава се да постоји само један програм који се бави чисто студијама безбедности или стратешким студијама, а остали се односе највећим делом на међународне односе. Претрага мастер студија кроз исте филтере даје 328 резултата, од којих 9 програма обухвата сферу која се односи на шире виђење студија безбедности и стратешких студија (искључујући програме који су чисто међународни односи или политикологија).

С обзиром на то да остале земље немају јавно доступне централизоване службе које се системски баве представљањем могућности за студије у њиховим државама, биле су потребне претраге генералних база података, од којих су се као најрелевантније показале базе података које представљају програме за студирање у иностранству (Findamasters ${ }^{20}$, Heysuccess ${ }^{21}$, Postgrad 22 ). Резултати показују сличан однос основних и мастер студија по питању стратешких студија, међународних односа и политичких наука. У наведено разматрање могуће је укључити и сагледавање студијских програма војних академија. Упркос ставу академске заједнице да су стратешке студије доминантно ствар цивилне академске заједнице, може се поћи и од става да су официрима 21. века потребна шира знања из области одбране, па и стратешких студија, да ће један број свршених питомаца наћи своје професионално ангажовање и у цивилном сектору

\footnotetext{
18 Анализа рађена 2019. године за потребе Катедре стратешких и одбрамбених студија Факултета безбедности.

${ }^{19}$ Deutscher Akademischer Austauschdienst: https://www.daad.de/en (Accessed on: 15.8.2020)

20 Findmasters, интернет портал за проналажење студијских програма: www.findamasters.com (Приступљено: 15.8.2020.)

${ }^{21}$ Heysuccess, интернет портал за проналажење студијских програма:https://www.heysuccess.com (Приступљено: 15.8.2020.)

22 Postgrad, интернет портал за проналажење студијских програма:https://www.postgrad.com (Приступљено: 15.8.2020.)
} 
одбране. Посебно је значајно напоменути да највећи број војних академија на постдипломском нивоу даје могућност укључивања и цивилних студената.

Уз уважавања постојећег стања, које показује мали број програма фокусираних на специфичну проблематику стратешких студија и заступљеност мањег броја предмета у оквиру ширих дисциплина, даће се приказ и компарација програма основних и мастер студијама на пет престижних универзитета. Додатно ограничење за дубљу анализу и прецизнију компарацију јесте и чињеница да доступни курикулуми онемогућавају приступ конкретном силабусу предмета, што не даје довољну количину информација за разумевање сржи програма и знања које се жели пренети тим предметом, као и то да се углавном ради о предметима са општим насловима, попут Увод у стратешке студије или само Стратешке студије.

Компарација програма основних и мастер студијама у наредним поглављима засниваће се на поређењу следећих универзитета:

- Цингхуа универзитет (Tsinghua University), Народна Република Кина

- Универзитет у Бристолу (University of Bristol), Уједињено Краљевство

- Џонс Хопкинс Универзитет (Johns Hopkins University), Сједињене Америчке Државе

- Московски државни институт за међународне односе (Moscow state institute for international relations - MGIMO), Руска Федерација

- Универзитет Sciences Po (Sciences Po ), Република Француска

\section{Програми основних студија}

Студијски програми на основним студијама који се баве искључиво стратешким студијама готово да не постоје. ${ }^{23}$ Непостојање програма експлицитно означеног као Стратешке студије не подразумева и непостојање преношења одређених знања садржаних у оквиру стратешких студија, било директно било кроз студије међународне безбедности. То је видљиво кроз курикулуме свих пет одабраних високошколских установа. Највећи број предмета који тангирају ка стратешким студијама нису означени стратешким префиксом. Штавише, ти предмети су општијег карактера и знатно су ближи међународној безбедности. Међутим, велики број војних изазова, ризика и претњи по међународну безбедност даје нам за право да претпоставимо да значајан сегмент предмета садржи у себи материју од значаја за стратешке студије. У пар случајева, присутни су предмети од значаја по унутрашњу безбедност, сајбер безбедност, односно геополитику. ${ }^{24}$

23 У овкиру посматраних држава једина високошколска установа која се издваја по овом питању јесте West Point Академија која у оквиру својих студија има програм Студија одбране и стратешких студија West Point Military Academy, major in Defense and Strategic Studies:

https://westpoint.edu/military/department-of-military-instruction/defense-and-strategicstudies (Приступљено: 15.8.2020.)

24 Примери конкретних предмета су: Наука, технологија и међународна безбедност, Студије рата и мира, Увод у нетрадиционалну безбедност (Цингхуа универзитет); 
Можда најоптималније решење нуде програмски садржаји универзитета Sciences Po. Академски приступ јасно одређује тежиште школовања на основним студијама које започиње усвајањем основних знања из друштвених и хуманистичких наука пре прелажења на знања из специфичних области које обухватају и стратешке студије. Сличан приступ има и Џонс Хопкинс универзитет. Са друге стране, Цингхуа универзитет и МГИМО задржавају фокус на традиционалнијим приступима, са изузецима у случају Цингхуа универзитета на предмету Увод у нетрадиционалну безбедност и у случају МГИМО-а на предмету Критичка геополитика. Тиме се условно могу поделити два приступа основном високошколском образовању на источни, ригиднији и са мање избора предмета и западни, флексибилнији, са већом могућношћу одабира. Универзитет у Бристолу стоји између ова два приступа и прави постепену прогресију већ од прве године, од ригиднијег приступа, са више обавезних и мање изборних, ка флексибилнијем, са мање обавезних и више изборних. Међутим, сви факултети садрже у корпусу обавезних предмета опште предмета који су најчешће увод у даље школовање. 25

Посебно је потребно нагласити искуство Универзитета Sciences Po и регионалне усмереност његових програма, у оквиру којих се студенти на општим студијама опредељују за једна од светских региона или за подрегионални ниво, који опредељује целокупно школовање (Европу, Медитеран, Блиски исток....). Ово почетно опредељење одређује избор предмета који се вишим степенима школовања све више усмеравају на теме одабраног региона. Сличан је приступ има и Џонс Хопкинс по питању регионалног приступа, међутим, образовни систем САД-а се разликује по могућностима одабира примарне и секундарне специјализације, те се студенти охрабрују у томе да секундарна специјализација

Политика моћи и међународни односи у Источној Азији, Управљање кроз небезбедност: институције и проблеми у савременом безбедносном управљању, Национализам и етнички конфликт у Јужној Азији, Студије критичке безбедности, Ризик, опасност и непогоде, Северна Ирска: студија случаја етнонационалног конфликта и разрешења (Универзитет у Бристолу); Полиција и затвори у компаративној перспективи, Политичка економија дроге и рата против дроге, Суверенитет: историјска перспектива и савремени проблеми, Идеје о моћи (Џонс Хопкинс); Лична безбедност и социјална одговорност, Моћ и институције у светској политици, Увод у међународну безбедност, Политика и безбедност у постсовјетској Евроазији, Стратегијска мисао и предвиђања, Оружани сукоби у XXI веку, Сајбер безбедност, Критичка геополитика (МГИМО); Политички поредак у сусрету са насиљем, Насиље, штета, срам, Државна неутралност: од толеранције до нихилизма, Геополитика ренесансне Европе - ратови, конфликти и дипломатија XIII-XVII века (Science Po).

25 Примери конкретних предмета су: Увод у међународну безбедност, Увод у теорију међународних односа, Компаративна политика (Цингхуа универзитет); Политички концепти, Савремена политичка теорија, Теорије међународних односа, Компаративна власт и политика: увод, Размишљати политички (Универзитет у Бристолу); Увод у глобалне студије, Проблеми међународног развоја (Џонс Хопкинс); Увод у међународне односе, Увод у политичке науке (МГИМО); Увод у политичке науке, Увод у социологију, Економија (Science Po). 
буде у вези са одређеним регионом (интересантно је да то није случај за мастер студије стратешких студија, које то експлицитно одбацују).

Истицање значаја регионалног усмерења на свим универзитетима кроз општи предмет територијалних студија наговештава ограничење генералног приступа у разумевању конкретних појава и процеса у конкретним регионима и ствара услове да специфичан регионални приступ може произвести боље разумевање и експланацију уколико се појединци што пре усмере на одређени регион. ${ }^{26}$ Територијалне студије саме по себи постоје као програми основних студија, при чему се за конкретне регионе одлучује даље на мастер студијама.

Економска димензија је саставни део студијских програма, чешће на мастер студијама, и веома често у директној вези са системом одбране и стратешким студијама. ${ }^{27}$ Значај економске перспективе у политичким и стратешким односима између држава уобличено је и кроз изборне блокове, превасходно на Џонс Хопкинсу и Science Po, где економски предмети сачињавају изборни блок у оквиру кога је обавезно узети одређен број предмета. Поред регионалног приступа и истицања значаја економских предмета заједнички именитељ свим плановима и програмима јесу и статистика, економетрије или квантитативне методологије. ${ }^{28}$

Ниво основних студија не пружа превише увида у начине приступања стратешким студијама од стране страних високошколских установа због ширег захвата и своје фокусираности на основе друштвених и политичких наука. Као општи предмети, они успостављају темеље на које се могу надграђивати стратешке студије, док истовремено пружају увиде у поједине сегменте од интереса стратешких студија. Разлика јесте у степену флексибилности при одабиру изборних предмета, где универзитети у западним земљама имају

26 Примери конкретних предмета су: Територијалне студије, Студије Јапана (Цингхуа универзитет); Политика моћи и међународни односи у Источној Азији, Политика субсахарске Африке, Политика ХИВ/СИДЕ у Африци и Национализам и етнички конфликт у јужној Азији (Универзитет у Бристолу); Урбано грађанство у Латинској Америци, Политика и поетика мобилности у Африци, Економско искуство земаља БРИК, Политика хаоса на Блиском истоку и надаље, Економски раст и развој у Источној Азији, Рана модерна Европа и шири свет (Џонс Хопкинс); Територијалне студије: Европа и Азија, Политика и безбедност у постсовјетској Евроазији (МГИМО); Дуж пута свиле, Актуелности у Оријенту и Медитерану, Културе и цивилизације Латинске Америке, Посткомунистичка транзиција: поређење Европе и Азије, Европска унија и Африка, Боко Харам: опасност за Африку?, Одбрана и безбедност у Азији и Трансатлантска стратегија: САД, ЕУ и будућност Запада (Science Po).

27 Примери предмета су: Безбедност и економија (Цингхуа универзитет), Политичка економија дроге и рата против дроге (Џонс Хопкинс), и Економија политике и међународних односа (МГИМО).

28 Примери предмета су: Основе статистике друштвених наука (Цингхуа универзитет), Принципи квантитативних друштвених наука (Универзитет у Бристолу), Статистика, Примењена статистика и увод у економетрију (МГИМО); Примењена математика, Квантитативне методе у друштвеним наукама, Квантитативне и математичке методе за друштвене науке, Статистика, Увод у статистику примењену на друштвене науке (Science Po). 
флексибилнији приступ. Постојеће недостатке ови, али и слични факултети могу надоместити кроз међусобну сарадњу. МГИМО, Џонс Хопкинс и Science Po имају успостављену сарадњу и омогућавају својим студентима да годину проведу на неком од тих факултета. На Science Po то је чак и обавезно у трећој години, тако да се недостатак теоријског плурализма надопуњује институционалном сарадњом.

Опште правило и закључак на нивоу основних студија односи се на недостатке конкретних програма стратешких студија и значајније фокусирање на економска питања, регионални приступ и на квантитативне методе и статистичке технике.

\section{КОМПАРАЦИЈА ПРОГРАМА МАСТЕР СТУДИЈА}

За разлику од основних студија, мастер студије су знатно усредсређеније на питање стратешких студија, посебно у случају Џонс Хопкинс универзитета, који има мастер програм са конкретним бављењем стратешким студијама. За разлику од Џонс Хопкинс универзитета, остали програми нису експлицитно наведени као програми стратешких студија. Међутим, они у себи садрже бројне предмете који су у директној вези са овом облашћу.

На Џонс Хопкинс универзитету основу чини изучавање односа спољне политике и стратегије кроз велику или вишу стратегију (grand strategy). Сви програми имају усмерење ка спољној политици што имплицира и изучавање међународне политике у циљу разумевања суштине стратешких студија. Истовремено, програм мастер студија међународне безбедности Science Ро садржи у обе године мастер студија изборни блок стратегије, упућујући на обавезно изучавање проблематике стратешких студија. Штавише, и остали изборни блокови, попут безбедности, конфликата, као и рата и међународног права такође садрже предмете од интереса за стратешке студије. Science Ро обухвата широку област интересовања стратешких студија, од предмета Основе стратешке мисли, Студија критичне небезбедности до регионалног фокуса на Азију, постсовјетски простор, Африку и Европску унију. 29

29 Реализују се следећи предмети: Компаративна стратегија, Стратегијско наслеђе XX века, Разумевање употребе силе у светској политици, Кризни менаџмент и колективна одбрана у међународном контексту, Узроци ратова, Употреба војне силе, Елаборација система оружаних снага, Команданти војски и демократија, Компаративне високе стратегије и светски поредак, Студије рата, Спровођење стратегије, као општијих тема, свакако не без значаја, Science Po нуди и алтернативније приступе и теме. Свакако да и даље задржава регионални фокус кроз предмете попут Одбрана и безбедност у Азији, Безбедносни проблеми у пост-Совјетским државама, Наркоџихадизам у Сахелу, Менаџмент безбедносних криза у Африци, Пакистан на раскршћу - опет, Спољна и безбедносна политика ЕУ: Генеза, еволуција, потенцијал и лимити, мастер студије нуде и допуну у значајнијем броју предмета критичког приступа попут Анализа значаја перцепције ризика у геополитици данашњице, Увод у студије критичке безбедности, Околина, конфликт и људска безбедност, Хумана безбедност, Род и (не)безбедност. 
За разлику од претходно наведених програма, Универзитет у Бристолу нема значајна одступања у приступу мастер студијама у односу на основне студије, чак се и предмети присутни на основним студијама понављају на мастер студијама, што није пракса осталих универзитета. Универзитет у Бристолу уводи и родну димензију безбедности, окренуту ка феминистичком приступу, што представља одступање од осталих планова и програма. ${ }^{30}$ Потребно је истаћи да ови предмети отварају могућност за развијање нових алтернативних приступа безбедности.

Цингхуа универзитет више је окренут међународним односима са бројним предметима који се баве питањима спољне политике, у оквиру који се налазе и садржаји од значаја за стратешке студије, као што су предмети Међународна стратегија и Контрола оружја и међународна безбедност.

Програм МГИМО-а балансира између међународне и спољне политике и стратешких студија, узимајући неопходне елементе од оба. Као што је наведено у поглављу о стратегији и стратешких студија, без међународних односа и геополитике, контекст стратешких студија се не може добити, те је веза између њих неопходна. Ово је највидљивије у предмету Савремена руска спољна политика и стратегија, која управо спаја ова два појма. Поред тога, МГИМО не приступа искључиво из војне перспективе стратешким студијама, што је видљиво кроз предмет Модерна економска стратегија Русије, а у складу је и са Бофровим приступом стратегији. Поред ових предмета значајни су још и Непролиферација оружја за масовно уништење и глобални проблеми, Глобална безбедност и модерни међународни сукоби и Стратегијски обавештајни рад.

Поред Science Po регионални приступ на мастер студијама задржан је и на другим универзитетима, то показује пример да се Блиски исток у теорији међународних односа изучава на Универзитету у Бристолу, као и Русија - Источна Азија, Савремени трендови на МГИМО, Ратови у Авганистану, Безбедносни изазови Африке: Оружане снаге, владавина и побуне на Џонс Хопкинс.

Као новина појављују се предмети из сајбер безбедности. Изузев Цингхуа универзитета и донекле Универзитета у Бристолу (постоји предмет Дигитална економија и друштво), сви програми садрже предмете који се односе на сајбер безбедност. То су предмети попут Информационе безбедности, Природе и карактеристика сајбер конфликата Приватни сектор и сајбер безбедност (Џонс Хопкинс); сајбер безбедност, Политика медија у дигиталној ери (МГИМО); и сајбер безбедност: операционални изазови и изазови политика, Терористи, шефови криминалних група и сајбер криминалци: Глобални безбедносни ризици Насилних недржавних актера (Science Po). Као природна последица увођења сајбер безбедности у наставне програме наметнула се потреба изучавање области која се односи на прикупљања и заштиту информација. Стога су се појавили и предмети: Тајни обавештајни рад у дигиталном добу, Обавештајни рад и

30 Предмети: Род и безбедност, Род, мужевност(и) и међународни односи, Род и развој, Интерпретације рода, и Род, породица и миграције 
тероризам (Science Po); Стратегијски обавештајни рад (МГИМО); Амерички обавештајни рад: улога праксе и утицај (Џонс Хопкинс).

Увођењем сајбер безбедности отвара се и четврта димензију рата са сви потенцијалним облицима прожимања кроз стратешке студије. Стога и спознаја стратегијских утицаја држава у међународним односима није могућа без изучавање четврте димензије простора. Ако копно, море, и ваздух, и њихов утицај на стратегијске интеракције представљају већ рађене, али никад завршене теме, космос је новина 21. века и захтева већи истраживачки фокус и значаја за Стратешке студије и међународне односе.

Новина је и војна индустрија као део економски пакета који је присутан на програмима и на основним студијама. Војна индустрија има најдиректнији контакт између економије и стратегије, али и развоја технологије која доминантно утиче не само на ратоводство, већ и на сегменте политичког одлучивања и понашања у међународној заједници. Она представља посебан ресурс, без кога ниједна држава није у могућности да развије довољан ниво стратегијског капацитета. Војна индустрија значајно утиче на националну безбедност и аутономију логистичког снабдевања државе и изградњу њене моћи. Поред наведенога производња наоружања и војне опреме има значајну улогу у међународној трговини и стварању зависности код мање развијених земаља. Предмети који се директно фокусирају на ово питање јесу са Science Po-а под називом Војна индустрија: Власт и однос с влашћу, Политичка економија војне индустрије.

Приступи планова и програма мастер студија анализираних у овом поглављу упућују на следеће закључке: Спољна политика држава, мећународни односи, геополитика и безбедности представљају основу за разумевање стратешких студија и програмски се морају везати за основне студије. Уједно стратегијске интеракције држава одвијају се и у четвртој димензији простора, те у разматрање поред копна мора и ваздуха мора узети у обзир и космос. Тиме, разумевање специфичности ових простора и ограничења и могућности које пружају утичу на приступе кроз које се не само одвијају већ и развијају стратегијске интеракције. Разумевање таквих ограничења и могућности, које пружа геополитика, омогућавају потпуније разумевање и објашњење начина на који ће се ратови водити.

Надоградњом сајбер простора као специфичне равни или поља која у данашње флуидно и дигитално доба представља извор изазова, ризика и претњи, али и могућности за интеракције које се у одређеним околностима могу готово изједначити са стратегијским приступом. Не мање значајно, сајбер безбедност утиче на капацитете обавештајног рада. Потпуне, тачне и правовремене информације и њихов значај за стратегијске интеракције засигурно не представља новину у разматрањима с обзиром на то да је присутно још од Сун Цуа, међутим, флуидно дигитално доба данашњице захтева поновно разматрање приступања прикупљању и обради обавештајних података управо прилагођеним данашњици. 
Као новина у изучавању стратешких студија на мастер студијама може се истаћи и постојање регионалног приступа. Специфичности одређених региона могу да истакну значај одређених генералних сегмената стратешких студија. Да би регионални приступ изучавања стратешких студија добио пун мандат нужно је на основним студијама створити услове да се општа знања о међународним односима, геополитици и безбедности усвоје на адекватном нивоу, који омогућава њихову трансмисију на регионални аспект. Поред наведеног, један број познатих истраживачких института прати област стратешких студија:

- Центар за стратешке и међународне студије - Сједињене Америчке Државе ${ }^{31}$,

- Кинески институт међународних студија, Народна Република Кина ${ }^{32}$,

- Међународни институт за стратешке студије, Руска Федерација ${ }^{33}$,

- Међународни институт за стратешке студије, Велика Британија ${ }^{34}$,

- Немачки институт за међународне и безбедносне послове, Немачка ${ }^{35}$,

- Аустралијски институт за стратегијску политику, Аустралија ${ }^{36}$,

- Француски институт за међународне и стратешке послове, Република Француска ${ }^{37}$,

- Институт за студије безбедности Европске уније, ЕУ/Француска ${ }^{38}$,

- Стокхолмски институт за истраживања међународног мира, Краљевина Шведска ${ }^{39}$.

\section{СТРАТЕШКЕ СТУДИЈЕ У РЕПУБЛИЦИ СРБИЈИ}

Република Србија у својим високошколским програмима (укупно 2692) нуди могућност изучавања и области безбедности. Најопштије посматрано студијски програми који за тему имају безбедност (од безбедности, одбране, цивилне заштите, заштите на раду до заштите животне средине) постоје на факултетима и високим школама друштвено-хуманистичких, техничко-технолошких, природноматематичких и интердисциплинарних наука. Укупно је на факултетима на основним академским студијама акредитовано 38 студијских програма (укључујући и програме Војне академије), а на високим школама (академских и струковних студија) 26 студијских програма различитих профила.

\footnotetext{
31 Доступан на: https://www.csis.org (Приступљено: 15.8.2020.)

32 Доступан на: http://www.ciis.org.cn/english (Приступљено: 15.8.2020.)

33 Доступан на: https://en.riss.ru (Приступљено: 15.8.2020.)

34 Доступан на: https://www.iiss.org (Приступљено: 15.8.2020.)

35 Доступан на: https://www.swp-berlin.org/en (Приступљено: 15.8.2020.)

36 Доступан на: https://www.aspi.org.au (Приступљено: 15.8.2020.)

37 Доступан на: http://www.iris-france.org/en (Приступљено: 15.8.2020.)

38 Доступан на: https://www.iss.europa.eu (Приступљено: 15.8.2020.)

39 Доступан на: https://www.sipri.org (Приступљено: 15.8.2020.)
} 
На мастер студијама на факултетима постоји 44 студијска програма, а на високим школама у форми специјалистичких струковних студија 20 студијских програма и 5 мастер академских или струковних студија. Докторске студије на факултетима егзистирају са 8 студијских програма, а у оквиру Високе школе академских студија - Криминалистичко-полицијска академија постоје и три студијска програма докторских студија. ${ }^{40}$ Највећи број студијских програма техничкотехнолошких факултета и природно-математичког факултета не бави се изучавањем стратешких студија и доминантно се односи на заштиту животне средине, ванредне ситуације, заштиту на раду, војно-индустријско инжењерство, унутрашње послове и криминалитет. Тема стратешких студија у оквиру свих нивоа школовања најпријемчивија је Факултету безбедности због њеног мултидисциплинарног карактера и структуре наставних планова и програма факултета.

Уважавајући наведене дилеме око наставних програма анализираних страних универзитета, као и стварну потребу развоја стратешких студија на Факултету безбедности, образована је Катедра стратешких и одбрамбених студија. У формулисању нове структуре предмета и наставних садржаја Катедре пошло се од постојећег предмета на основним академским студијама у којим се изучавају кључне области за стратешке студије. Предмети попут Политички систем, Уводу студије безбедности, Међународни односи и Основи геополитике омогућавају разумевање ширег оквира неопходног за стратешке студије. ${ }^{41}$ Овим се задржавају неопходне политиколошке основе, али се истиче и безбедносни аспект, који је подједнако важан за стратешке студије. Надоградња безбедносног аспекта остварена је увођењем у Наставни план и програм за 2020/2021. годину, у надлежности Катедре стратешких и одбрамбених студија, једног броја изборних предмета које се детаљније фокусирају на стратешке студије. То се пре свега односи на: Стратегију и одбрану, Стратегију и технологију, Геополитику региона u Pam и цивилизацију. Наслањајући се на веома широк студијски програм мастер академских студија - Студија наука безбедности ${ }^{42}$, у коме се посебна изборна група односи на стратешку безбедност, на докторским академским студијама Студија наука безбедности, уведени су предмети: Cтратегија, одбрана и савремени ратови и Геополитика великих сила и стратешка безбедност малих држава. 43 Увођењем нових предмета који се доминантно баве стратешком мисли студентима свих нивоа студија се нуде садржаји који треба да омогуће упознавање са теоријом и праксом стратегије, као видом војно-политичке

\footnotetext{
40 Доступан на:: https://www.nat.rs/ishodi-akreditacije-i-spk (Приступљено: 15.8.2020.)

41 Доступан на: https://fb.bg.ac.rs/studije/oas/studije-nauka-bezbednosti-novi-studijskiprogram (Приступљено: 15.8.2020.)

42 МАC - Студије наука безбедности покривају обалст стратешких студија, националне безбедности, корпоративне безбеднсоти и еколошке безбедности.. Доступно на: https://fb.bg.ac.rs/studije/master-studije/studije-nauka-bezbednosti/

43 Доступно на: https://fb.bg.ac.rs/studije/doktorske-akademske-studije/doktorske-studije (Приступљено: 15.8.2020.)
} 
артикулације расположивих ресурса са задатим циљевима, историјским развојем стратегије и стратешког мишљења, као и практичним аспектима стратегијског и одбрамбеног планирања, развојем модерног ратоводства и утицајем технологије на савремено вођење рата. Сви наведени предмети имају своје упориште на светски признатим универзитетима.

Структура студија која је најчешћа на факултетима где се изучава наведена област реализује се у моделу $3+2$, а на Факултету безбедности 4+1. Разлика између 4+1 и 3+2 приступа односу између основних и мастер студија такође не представља проблем за Факултет безбедности. Начин реализације наставе Факултета безбедности суштински одражава специфичан модел приступу основном и мастер образовању које превазилази $3+2$ или 4+1 формулу, полазећи од чињенице да прве две године основног академског образовања дају широки обухват базичних научних дисциплина које су од значаја за проучавање безбедности, као и увођење у студије безбедности. Ово надомешћује постојеће приступе из следећих разлога: а) приступ безбедности захтева познавање основа из широког спектра дисциплина да би студенти добили свеобухватније разумевање места, значаја али и међуповезаности различитих начина угрожавања државе, друштва и појединаца, а не само политичких наука; б) полажење од широког спектра дисциплина омогућава студентима да боље идентификују сфере сопственог интересовања у којем би се даље усавршавали; и в) омогућавају студентима „шири поглед“, могућност креативнијег приступања безбедносној и уже стратегијској проблематици, превазилазећи ограничења уског погледа изазваног усавршавањем искључиво у једној дисциплини.

Друге две године студија основног академског образовања дају уже образовање у конкретном сегменту студија безбедности, фокусирајући се на конкретан сектор студија безбедности који представља надградњу над основама стеченим у прве две године. Кроз овакву надоградњу омогућава се студентима да се определе за сферу сопственог интересовања без бојазни да ће специјализација трпети од уског погледа због базичних знања стечених у прве две године. Тиме, уместо трогодишњег основног образовања, на основу којег се тек на мастеру усмерава на студије безбедности, основно образовање од почетка усмерава на студије безбедности и кроз базичне дисциплине. Отуда, додатна година образовања између 3+2 модела и модела основних студија на Факултету безбедности се суштински изједначава јер у оквиру 60 ЕСПБ додатне године $3+2$ модела се могу урачунати они предмети који нису од интереса за студије безбедности.

Једногодишњи мастер програм омогућава, на трагу тога, још уже усмерење, производећи специјалисте за одређене области, који већ поседују уже знање у оквиру студија безбедности. Представљајући континуитет у односу на трећу и четврту годину академског образовања, субспецијалност. Значајан искорак јесте, већ поменуто, увођење изборне групе на МАC - Стратешка безбедност, што подстиче даља промишљања да је паралелно са предметима који преносе знања рационално и увести предмета који доприносе развијању вештине попут: Анализа спољне политике (Универзитет у Бристолу); Доношење политика животне средине и анализа политика, Анализа одбране, Анализа ризика и 
моделовање (Џонс Хопкинс); Анализа међународних ситуација (МГИМО); Анализа значаја перцепције ризика у геополитици данашњице, Супротстављање кризи: алати за анализу и комуникацију (Science Po); као и увођење додатног броја методолошких предметима на свим нивоима као предуслов за усвајање предмета вештина.

\section{ЗАКЉУЧАК}

Једно од питања које се провлачи од завршетка Хладног рата односило се на будућност стратешких студија и њено формирање као засебне академске области. Можда најбољи одговор дали су Изабела Дејвестон и Џејмс Ворел (Isabelle Duyvesteyn \& James E. Worrally) у закључку свога рада „Глобалне стратешке студије: манифест“ (Global strategic studies: a manifesto): „Пре око 20 година Ричард Бетс је у прегледном чланку поставио питање „да ли стратешке студије треба да преживе?“44 Његов одговор тада је био јасан - да. Данас тврдимо да стратешке студије заиста имају светлу будућност ако ове изазове схватимо озбиљно и видимо их као подстицај и инспирацију за окупљање заједнице научника са новим фокусом. Радујемо се конструктивној расправи којој је овај манифест намењен, да изазове и поздрави идеје о томе како се поље може оживети и како стратешке студије могу постати заиста глобалне“. 45

Да би се та идеја остварила потребно је на универзитетима и факултетима, а посебно на оним које у својој матичности имају мултидисцилинарне програме, развијати, смерове и предметне садржаје везане за област стратешких студија.

Актуелни тренутак и стање планова и програма усмерених на стратешке студије високошколских установа из Сједињених Америчких Држава, Велике Британије, Европске уније (Француска), Руске Федерације и Народне Републике Кине производи следеће генералне закључке: Стратешке студије не представљају фокус изучавања на основним студијама, најчешће посматрани као субдисциплина политичких наука и међународних односа; На мастер студијама постоји значајније усмерење ка стратешким студијама, али уз постојање мањег броја програма који се експлицитно називају Стратешким студијама; Између „Истока“ и „Запада“ постоји разлика у приступу образовању по питању флексибилности плана и програма на студијама. „Западни“ приступ омогућава већу флексибилност у одабиру предмета док је „источни“ приступ ригиднији по овом питању. Велики број наставних планова и програма имају снажну регионалну димензију, фокусирајући се на стратешке студија у конкретним регионалним оквирима. Сви планови и програми у себи садрже значајан скуп економских предмета и квантитативних метода научног истраживања наглашавајући њихов значај за стратешке студије. Између страних

${ }_{44}$ Richard K. Betts, „Should Strategic Studies Survive?“, World Politics, Vol. 50, No. 1, 1997, pp. 7-33.

45 Isabelle Duyvesteyn \& James E. Worrall, "Global strategic studies: a manifesto", Journal of Strategic Studies, Vol. 40, N. 3, 2017, p. 355. 
високошколских установа, са посебним акцентом на Science Po, Џонс Хопкинс и МГИМО, постоји развијена институционална сарадња и размена. Тиме су ове установе у могућности да својим студентима понуде стицање знања која превазилазе план и програм матичне институције. Овим се омогућава да се тематика стратешких студија, коју је готово немогуће заокружити и детаљно изучавати у оквиру једног програма, надопуњује студентском разменом.

Почетни искораци, учињени на Факултету безбедности, око уобличавања предмета и наставних садржаја усмерених на стратешке студије дају добру основу за едукацију студената усмерену пре свега на развој: свести о значају стратегијске културе; способности препознавања узрока рата и услова мира; вештине сагледавања односа и утицаја политике, међународних односа и безбедносних студија на стратегију; умеће препознавања савремених проблема стратешких студија у контексту савремених безбедносних изазова; праксе формулисања, израде и имплементације стратегија, стратешких планова и доктрина. Посебно је потребно код студената створити претпоставке за усвајање и надоградњу постојећих теорија; предуслове за критичко промишљање, као и могућност сагледавања будућег развоја ове дисциплине.

Мишљења сам да Факултет безбедности треба да тежи даљем развоју свог 4+1 модела кроз увећање броја изборних модула на трећој и четвртој години студија, кроз које ће дати шира сазнања из сегмента проучавања стратешких студија. Кроз овакав приступ Факултет безбедности може задржати сопствену специфичност, која му даје компаративну предност у односу на остале факултете. Истовремено у складу са постојећим ресурсима Факултет безбедности треба да тежи увећању броја мастер програма која би представљала стратешке студије, пратећи изборне модуле на трећој и четвртој години.

Поред наведеног, полазећи од анализе планова и програма Универзитета у иностранству, потребно је у активностима на изради нових наставних планова и програма подићи ниво флексибилности одабира предмета са годинама студија, увести регионално усмерења кроз увођење одређених аспеката регионалних/територијалних студија, инклузију одређених аспеката економије и увођења економских предмета који би пратили динамику 4+1 модела и оснажење предмета аналитичких вештина.

\section{БИБЛИОГРАФИЈА}

\section{Књиге ч чланци:}

1. Ayson, Robert, Old wine in new bottles? The continued relevance of Cold War strategic concepts. In: Glenn, Russell W. New Directions in Strategic Thinking: ANU Strategic \& Defence Studies Centre's Golden Anniversary Conference, ANU Press, 2018.

2. Bernard Brodie, "Strategy as a Science", A Quarterly Journal of International Relations, July 2019, pp. 467-488. 
3. Buzan, Berry, An Introduction to Strategic Studies - Military Tehnology \& International Relations, Macmillan for International Institute Strategic Studies, London, 1987.

4. Бофр, Андре, Увод у стратегију, Војноиздавачки завод, Београд, 1968.

5. Владимир Ајзенхамер, Стратешке студије од војних наука до студија безбедности, у зборнику: Владимир Н. Цветковић, „Науке безбедности - врсте и облици“, Универзитет у Београду, Факултет безбедности, 2020.

6. Isabelle Duyvesteyn \& James E. Worrall, Global strategic studies: a manifesto, Journal of Strategic Studies, 2017, Vol. 40, No. 3, pp. 347-357.

7. Colin S. Gray, The Practice of Strategy, In: John Baylis, James J. Wirtz, Colin S. Gray, "Strategy in the Contemporary Word", Oxford University Press, 2019.

8. Colin Gray, Strategy and Defence Planning, Oxford University Press, Oxford, 2016

9. Colin Gray, Strategy and Politics, Routledge, London and New York, 2016.

10. John Baylis, James J. Wirtz, Introduction Strategy in Contemporary World, in John Baylis, James J. Wirtz, and Colin S. Gray, "Strategy in the Contemporary Word", Oxford University Press, 2018.

11. Јефтић Зоран, Младеновић Мирослав, Роквић Вања, Основе цивилно-војних односа, Универзитет у Београду Факултет безбедности, Београд, 2014.

12. John Baylis, James J. Wirtz, and Colin S. Gray, Strategy in the Contemporary Word, Oxford University Press, 2019.

13. Lawrence Фreedman, Strategy A History, Oxford University Press, Oxford, 2013.

14. Betts, Richard K., "Should Strategic Studies Survive?", World Politics, 1997, Vol. 50, No. 1, pp. 7-33.

15. Walt, Stephen M., "The Renaissance of Security Studies", International Studies Quarterly, 1991, Vol. 35, No. 2. pp. 211-239.

\section{Интернет извори:}

1. http://www.vs.rs/sr_lat/o-vojsci/opste/misije-i-zadaci 15.8.2020.)

2. https://repository.upenn.edu/cgi/viewcontent.cgi?article=1012\&context=think_ta nks (Приступљено: 15.8.2020.)

3. https://www.daad.de/en (Приступљено: 15.8.2020.)

4. www.findamasters.com (Приступљено: 15.8.2020.)

5. https://www.heysuccess.com (Приступљено: 15.8.2020.)

6. https://westpoint.edu/military/department-of-military-instruction/defense-andstrategic-studies (Приступљено: 15.8.2020.)

7. https://www.nat.rs/ishodi-akreditacije-i-spk (Приступљено: 15.8.2020.)

8. https://fb.bg.ac.rs/studije/oas/studije-nauka-bezbednosti-novi-studijski-program (Приступљено: 15.8.2020.)

9. https://fb.bg.ac.rs/studije/master-studije/studije-nauka-bezbednosti (Приступљено: 15.8.2020.)

10. https://fb.bg.ac.rs/studije/doktorske-akademske-studije/doktorske-studije (Приступљено: 15.8.2020.)

11. https://www.csis.org (Приступљено: 15.8.2020.)

12. http://www.ciis.org.cn/english (Приступљено: 15.8.2020.)

13. https://en.riss.ru (Приступљено: 15.8.2020.)

14. https://www.iiss.org (Приступљено: 15.8.2020.) 
15. https://www.swp-berlin.org/en (Приступљено: 15.8.2020.)

16. https://www.aspi.org.au (Приступљено: 15.8.2020.)

17. https://www.iss.europa.eu (Приступљено: 15.8.2020.)

18. https://www.sipri.org (Приступљено: 15.8.2020.)

\section{EDUCATION AS A PREREQUISITE FOR SUCCESSFUL DEVELOPMENT OF STRATEGIC STUDIES}

As an integral part of political science, international relations, or more specifically security studies, strategic studies can be understood as a link between military means and political goals. In theory and practice, this implies an interdisciplinary approach to study, starting with politics, economics, sociology, psychology, technology, geospace to power structure and tactics. Strategic thinking and the strategy itself are needed not only for state decision makers, military leaders, holders of power in large corporations, but also for everyday life and problem solving and achieving certain goals that we declare strategic and that do not have a routine character. We invoke strategy whenever the path for achieving a goal is not easy and when an efficient and effective approach and order in procedures and procedures is required. Strategic decision-making is always presented to people of the greatest power and who are far more important than those who offer only advice or are in charge of implementation. For all of them, the complexity of the phenomenon, a large number of factors that need to be taken into account in order to raise the level of chances to achieve the goal, imposes the need for adequate education of strategic studies, from consulting a large number of publications to study programs at all levels of academic education. The paper will deal with the issue of education as a prerequisite for the development of strategic thought and skills as well as the presentation of the development of study programs and practice of study curricula of Strategic Studies in the EHEA countries. Drawing upon the importance of studying strategic studies at all levels of academic education, the paper will start from the basic assumption that study programs, which refer to Strategic Studies, are not sufficiently present in basic academic studies in terms of content and scope. The result of this paper should indicate the need to consider the new security agenda and strategy, and consequently the introduction of modern program contents of strategic studies intended for future civilian and military experts as well as strategic decision makers.

Keywords: strategic studies, education strategy, study programs 